\title{
STRUCTURAL AND MAGNETIC CHARACTERIZATION OF MAGHEMITES PREPARED FROM Al-SUBSTITUTED MAGNETITES $^{(1)}$
}

\author{
Marcelo Augusto Batista ${ }^{(2)}$, Antonio Carlos Saraiva da Costa ${ }^{(3)}$, Jerry Marshal Bigham ${ }^{(4)}$, \\ Andrea Paesano Junior ${ }^{(5)}$, Graciele Berndt ${ }^{(6)}$, Tadeu Takeyoshi Inoue ${ }^{(2)}$ \& Adriele Galeti \\ Nonaka ${ }^{(7)}$
}

\begin{abstract}
SUMMARY
Synthetic aluminum-substituted maghemites were characterized by total chemical analysis, powder X-ray diffraction (XRD), Mössbauer spectroscopy (ME), and vibrating sample magnetometry (VSM). The aim was to determine the structural, magnetic, and hyperfine properties of $\gamma-\mathrm{Fe}_{2-\mathrm{x}} \mathrm{Al}_{\mathrm{x}} \mathrm{O}_{3}$ as the $\mathrm{Al}$ concentration is varied. The XRD results of the synthetic products were indexed exclusively as maghemite. Increasing $\mathrm{Al}$ for $\mathrm{Fe}$ substitution decreased the mean crystalline dimension and shifted all diffraction peaks to higher ${ }^{\circ} 2 \theta$ angles. The $a_{0}$ dimension of the cubic unit cell decreased with increasing $\mathrm{Al}$ according to the equation $\mathrm{a}_{\mathrm{o}}=0.8385-3.63 \times 10^{-5} \mathrm{Al}\left(\mathrm{R}^{2}=0.94\right)$. Most Mössbauer spectra were composed of one sextet, but at the highest substitution rate of $142.5 \mathrm{mmol} \mathrm{mol}^{-1} \mathrm{Al}$, both a doublet and sextet were obtained at $\approx 300 \mathrm{~K}$. All hyperfine parameters from the sub-spectra were consistent with high-spin $\mathrm{Fe}^{3+}\left(0.2 \mathrm{a} 0.7 \mathrm{mms}^{-1}\right)$ and suggested a strong superparamagnetic component associated with the doublet. The magnetic hyperfine field of the sextets decreased with the amount of Al-substitution $\left[B_{h f}(T)\right.$ $\left.=49.751-0.1202 \mathrm{Al} ; \mathrm{R}^{2}=0.94\right]$ while the linewidth increased linearly. The saturation magnetization also decreased with increasing isomorphous substitution.
\end{abstract}

Index terms: isomorphous substitution, hyperfine parameters, spinel, ferromagnetic.

\footnotetext{
(1) Received for publication on April 30, 2013 and approved on August 30, 2013.

(2) Adjunct Professor, Departament of Agronomy, State University of Maringá - DA/SUM. Av. Colombo, 5790, Bloco J-45. CEP 87020-900 Maringá (PR), Brazil. E-mail: mabatista@uem.br, ttinoue@uem.br

(3) Associate Professor, DA/SUM. E-mail: antoniocscosta@gmail.com

(4) Faculty Emeritus, School of Environment and Natural Resources, 2021 Coffey Road, Ohio State University, Columbus, OH 43210, USA. E-mail: bigham1@osu.edu

(5) Full Professor, Departament of Physic, SUM - DP/SUM. E-mail: paesano@wnet.com.br

(6) Doctoral student, DP/SUM. E-mail:graberndt@gmail.com

(7) Master student in Agronomy, DA/SUM. E-mail: adriele_gn@hotmail.com
} 


\title{
RESUMO: CARACTERIZAÇÃO ESTRUTURAL E MAGNÉTICA DE MAGHEMITAS PREPARADAS A PARTIR DE MAGNETITAS SUBSTITUÍDAS COM Al
}

\begin{abstract}
Maghemitas sintéticas substituídas com Al foram caracterizadas por meio de análise química total, difratometria de raios-X (DRX), espectroscopia Mössbauer (EM) e magnetometria de amostra vibrante (MAV). Objetivou-se com este trabalho determinar as propriedades estruturais, magnéticas e hiperfinas de $\gamma-\mathrm{Fe}_{2-x} \mathrm{Al}_{x} \mathrm{O}_{3}$, conforme a variação da concentração de Al.Os resultados de DRX dos produtos sintéticos foram indexados somente para maghemita. Com o aumento da substituição de Fe por Al, o diâmetro médio do cristalito diminuiu e levou todos os picos de difração para maiores ângulos ${ }^{\circ} 2 \theta$. A dimensão $a_{0} d a$ cela unitária cúbica decresceu com o aumento de $\mathrm{Al}$, de acordo com a equação $a_{o}=0,8385-3,63 \times 10^{-5} \mathrm{Al}\left(R^{2}=0,94\right)$. A maioria dos espectros Mössbauer foi composta de um sexteto, mas na taxa mais alta de substituição de $142,5 \mathrm{~m} \mathrm{~mol} \mathrm{~mol}^{-1} \mathrm{Al}$ um doubleto e sexteto foram obtidos a $\approx 300 \mathrm{~K}$. Todos os parâmetros hiperfinos do subespectro foram consistentes com o alto spin $\mathrm{Fe}^{3+}\left(0,2\right.$ a $\left.0,7 \mathrm{mms}^{-1}\right)$ e sugeriram um forte componente superparamagnético associado com o dubleto. O campo magnético hiperfino dos sextetos decresceram com a substituição de $A l\left[B_{h f}(T)=49,751\right.$-0,1202Al; $\left.R^{2}=0,94\right]$, enquanto as larguras da linha aumentaram de forma linear. A magnetização de saturação também diminuiu com o aumento da substituição isomórfica.
\end{abstract}

Termos de indexação: substituição isomórfica, parâmetros hiperfinos, espinélio, ferrimagnético.

\section{INTRODUCTION}

The ferrimagnetic mineral maghemite $\left(\gamma-\mathrm{Fe}_{2} \mathrm{O}_{3}\right)$ is closely related with metal availability and $\mathrm{P}$ adsorption capacity. Magnetization is spontaneous in a significant percentage of Brazilian soils. In the State of Paraná (Brazil) the area of magnetic soils represents nearly 50 \% (Costa et al., 1999).

Magnetic soils are common in many parts of the world. These soils show spontaneous magnetization of more than $1 \mathrm{~J} \mathrm{~T}^{-1} \mathrm{~kg}^{-1}$ and, as a result, are attracted to a hand magnet. The minerals that are responsible for this characteristic are magnetite $\left(\mathrm{Fe}_{3} \mathrm{O}_{4}\right)$ and, especially, fine-grained maghemite $\left(\gamma-\mathrm{Fe}_{2} \mathrm{O}_{3}\right)$. In Brazil, magnetic soils comprise up to $5 \%$ of the total land area (Resende et al., 1986) and soil magnetic properties have been utilized in a variety of earth science studies, such as soil genesis, erosion, pollution (Chen et al., 2005), metal availability (Roy \& Bhattacharya, 2012), and P adsorption capacity (Vilar et al., 2010). Electromagnetic and magnetic sensors are also frequently used for detection of buried objects (military ordnance, pipelines, etc), but their performance is often compromised in magnetic soils. Hence, it is important for both academic and practical reasons to understand the origin of variations in magnetic soil properties.

Recently, many studies have investigated natural and synthetic maghemites because of their importance in magnetic soils (Souza Junior et al., 2010; Silva et al., 2010; Batista et al., 2010; Batista et al., 2011). Maghemite $\left(\gamma-\mathrm{Fe}_{2} \mathrm{O}_{3}\right.$ or $\left.\mathrm{Fe}_{8 / 3} \square_{1 / 3} \mathrm{O}_{4}\right)$ is a cation-deficient spinel with $\mathrm{Fe}^{3+}$ ions distributed among both tetrahedral (A) and octahedral (B) sites. The number of $\mathrm{B}$ sites is twice that of A. One-third of the total cation sites are vacant ( $\square$ ), and the distribution of these vacancies is some what controversial, as they are reported to occur either exclusively at B sites, or at both A and B sites (Armstrong et al., 1966). Both tetragonal and cubic structures are possible, depending on whether or not all vacancies are at the B sites and ordered (Armstrong et al., 1966).

Pure maghemites are rarely, if ever, found in nature. Isomorphic substitution (IS) of $\mathrm{Fe}$ by different elements is common, but the effects of solid solution on the structural and magnetic properties of maghemite are difficult to define in natural samples, where the concentration and physical parameters of the magnetic fraction are seldom known with accuracy. In synthetic samples, these conditions can be controlled (van Oorschot \& Dekkersa, 1999).

A variety of techniques is available to analyze iron minerals. In the last three decades, Mössbauer spectroscopy (MS) has become an increasingly important analytical tool for the characterization of synthetic and natural $\mathrm{Fe}$-containing materials, and one of the most rapidly growing application areas of this technique is undoubtedly that of soils and sediments (Ferreira et al., 2003). In soils, Al commonly replaces part of the $\mathrm{Fe}$ in maghemite (Schwertmann \& Fetcher, 1984). The study of Almaghemites by MS has been difficult because $\mathrm{Al}$ can, in principle, occupy both A and B cation sites, or can show a preference for one over the other (Wolska \& Schwertmann, 1989; Bowen et al., 1994). In this work, we characterized aluminum-substituted maghemites synthesized by thermal alteration of coprecipitated $\mathrm{Fe} / \mathrm{Al}$ magnetites. The aim was to determine the structural, magnetic, and hyperfine properties of $\gamma-\mathrm{Fe}_{2-\mathrm{x}} \mathrm{Al}_{\mathrm{x}} \mathrm{O}_{3}$ as the $\mathrm{Al}$ concentration is varied. 


\section{MATERIAL AND METHODS}

\section{Synthesis method}

Precursor magnetites were synthesized following the Schwertmann \& Cornell (1991) procedure with some modifications. Aqueous solutions of $\mathrm{FeSO}_{4}$ and $\mathrm{Al}_{2}\left(\mathrm{SO}_{4}\right)_{3}$ were mixed in different ratios to attain nominal replacement values of $\mathrm{Al}^{3+}$ for $\mathrm{Fe}^{3+}$, ranging from 0.0 to $300.0 \mathrm{mmol} \mathrm{mol}^{-1}$ in the general chemical formula $\gamma-\mathrm{Fe}_{2 " x} \mathrm{Al}_{\mathrm{x}} \mathrm{O}_{3}$. The reaction was conducted at $90{ }^{\circ} \mathrm{C}$ under $\mathrm{N}_{2}$ atmospheric conditions. With the addition of an alkali (KOH $1 \mathrm{~mol} \mathrm{~L}^{-1}$ ) to the solution, a bluish material precipitated, which evolved to a dark powder (magnetite) in less than $1 \mathrm{~h}$ and was easily attracted to a hand magnet. All synthetic materials were washed free of salts with deionized water, frozen under liquid $\mathrm{N}_{2}$, and freeze-dried. The magnetites were transformed to maghemites by heating at $250{ }^{\circ} \mathrm{C}$ for $4 \mathrm{~h}$ in a forced draft oven. In order to purify the maghemites, poorly crystalline materials were selectively removed one by one, in a 4 -h treatment with acid (pH 3.0) ammonium-oxalate $\left(2.0 \mathrm{~mol} \mathrm{~L}^{-1}\right)$ in the dark, using a sample-to-solution ratio of 1:1000, according to the procedure described in McKeague \& Day (1966).

\section{Characterization}

The chemical composition of the powdered materials was verified after dissolution with hot $\left(75^{\circ} \mathrm{C}\right)$, concentrated $(1: 1 \mathrm{v} / \mathrm{v}) \mathrm{H}_{2} \mathrm{SO}_{4}$. Iron and $\mathrm{Al}$ in solution were determined using inductively coupled plasma mass spectrometry (ICP-MS). Powder XRD analysis was carried out on a Shimadzu D6000 equipment, using a $\mathrm{Cu}-\mathrm{K} \alpha(\lambda=0.15418 \mathrm{~nm})$ beam and Ni filter. The XRD was conducted with scanning steps of $0.02^{\circ}(2 \theta)$, with $0.6 \mathrm{~s}$ for the time of pulse accumulation. The X-ray diffraction patterns were used to evaluate the unit cell parameter, $\mathrm{a}_{0}$, and the mean crystal diameter size (MCD), d, was calculated based on Scherrer's formula. Mössbauer spectroscopy (MS) in transmission geometry was performed using a conventional Mössbauer spectrometer in constant acceleration mode. The $\lambda$-rays were provided by a ${ }^{57} \mathrm{Co}$ (Rh) source. The Mössbauer spectra were analyzed using a non-linear, least-square routine with Lorentzian line shapes and a fixed linewidth $(\Gamma)$. All isomer shift (IS) data given are relative to $\alpha$-Fe throughout this paper. Magnetization measurements were performed using a vibrating sample magnetometer (VSM) at room temperature. The Vibrating Sample Magnetometer (VSM) provides hysteresis loops for the samples, from which parameters such as coercivity, coercivity of remanence, and saturation magnetization can be determined.

\section{RESULTS AND DISCUSSION}

It was possible to synthesize maghemites with different degrees of isomorphous substitution (IS) ranging from $0-142.5 \mathrm{mmol} \mathrm{mol}^{-1}$. However, the IS values observed in the synthesized $\mathrm{Al}$-maghemites were lower than expected if $\mathrm{Al}$ was completely miscible with $\mathrm{Fe}$ in the maghemite structure (Table 1). The difference between expected and observed values must be associated with the properties of $\mathrm{Al}$, since Batista et al. (2008), studying synthetic Zn-substituted maghemites and using the same synthesis conditions, observed variations smaller than $2 \%$ between the expected and observed IS values. Another possibility to explain the differences is the occupancy of site A and B. Costa et al. (2007), working with $\mathrm{Zn}^{2+}$ substituted magnetites, observed $\mathrm{Zn}^{2+}$ substitution only at the A cation sites. On the other hand, some researchers working with $\mathrm{Al}$-substituted maghemites (Wolska \& Schwertmann, 1989; Costa et al., 1995) have observed $\mathrm{Al}$ mainly in the B sites. Moreover, the synthesis methodology used in this study was first described for pure magnetite synthesis (Schwertmann \& Cornell, 1991).

Figure 1 presents the X-ray diffraction patterns for selected samples. Only maghemite diffraction lines were observed (i.e., no impurities were detected). The diffractograms could be indexed to a cubic spinel structure similar to that obtained from the Joint Committee for Powder Diffraction Standards (JCPDS - databasecard \# 39-1.346). The diffraction peaks moved to higher $2 \theta$ angles with increasing Alsubstitution indicating a systematic decrease of the $a_{0}$ unit cell parameter. This behavior was observed for the six most intense diffraction lines and was related to the fact that $\mathrm{Fe}^{3+}$ has a larger ionic radius $(\mathrm{r}=0.064 \mathrm{~nm})$ than $\mathrm{Al}^{3+}(\mathrm{r}=0.053 \mathrm{~nm})$. Schwertmann $\&$ Fechter (1984) observed that maghemites from highly weathered soils with a high degree of $\mathrm{Fe}$ replacement by $\mathrm{Al}$ had significantly lower unit cell dimensions than pure maghemites. In addition, a decrease in peak intensities and an increase in full width at half maximum (FWHM) of diagnostic diffraction peaks were observed. These alterations

Table 1. Isomorphic substitution (IS) of $\mathrm{Fe}$ for $\mathrm{Al}$ in the synthetic maghemites

\begin{tabular}{ccc}
\hline IS expected & IS observed & $\mathbf{F e}_{2-\mathbf{x}} \mathrm{Al}_{\mathbf{x}} \mathbf{O}_{3}$ \\
\hline & $\mathrm{mmol} \mathrm{mol}^{-1}$ & \multicolumn{2}{c}{$\mathrm{mol}$} \\
\cline { 1 - 2 } 0.0 & 0.0 & $\mathrm{Fe}_{2.00} \mathrm{Al}_{0.00} \mathrm{O}_{3}$ \\
12.5 & 8.4 & $\mathrm{Fe}_{1.98} \mathrm{Al}_{0.02} \mathrm{O}_{3}$ \\
25.0 & 18.2 & $\mathrm{Fe}_{1.96} \mathrm{Al}_{0.04} \mathrm{O}_{3}$ \\
37.5 & 28.1 & $\mathrm{Fe}_{1.94} \mathrm{Al}_{0.06} \mathrm{O}_{3}$ \\
50.0 & 36.9 & $\mathrm{Fe}_{1.93} \mathrm{Al}_{0.07} \mathrm{O}_{3}$ \\
75.0 & 53.5 & $\mathrm{Fe}_{1.89} \mathrm{Al}_{0.11} \mathrm{O}_{3}$ \\
100.0 & 69.8 & $\mathrm{Fe}_{1.86} \mathrm{Al}_{0.14} \mathrm{O}_{3}$ \\
150.0 & 97.6 & $\mathrm{Fe}_{1.80} \mathrm{Al}_{0.20} \mathrm{O}_{3}$ \\
200.0 & 118.8 & $\mathrm{Fe}_{1.76} \mathrm{Al}_{0.24} \mathrm{O}_{3}$ \\
300.0 & 142.5 & $\mathrm{Fe}_{1.71} \mathrm{Al}_{0.29} \mathrm{O}_{3}$ \\
\hline
\end{tabular}




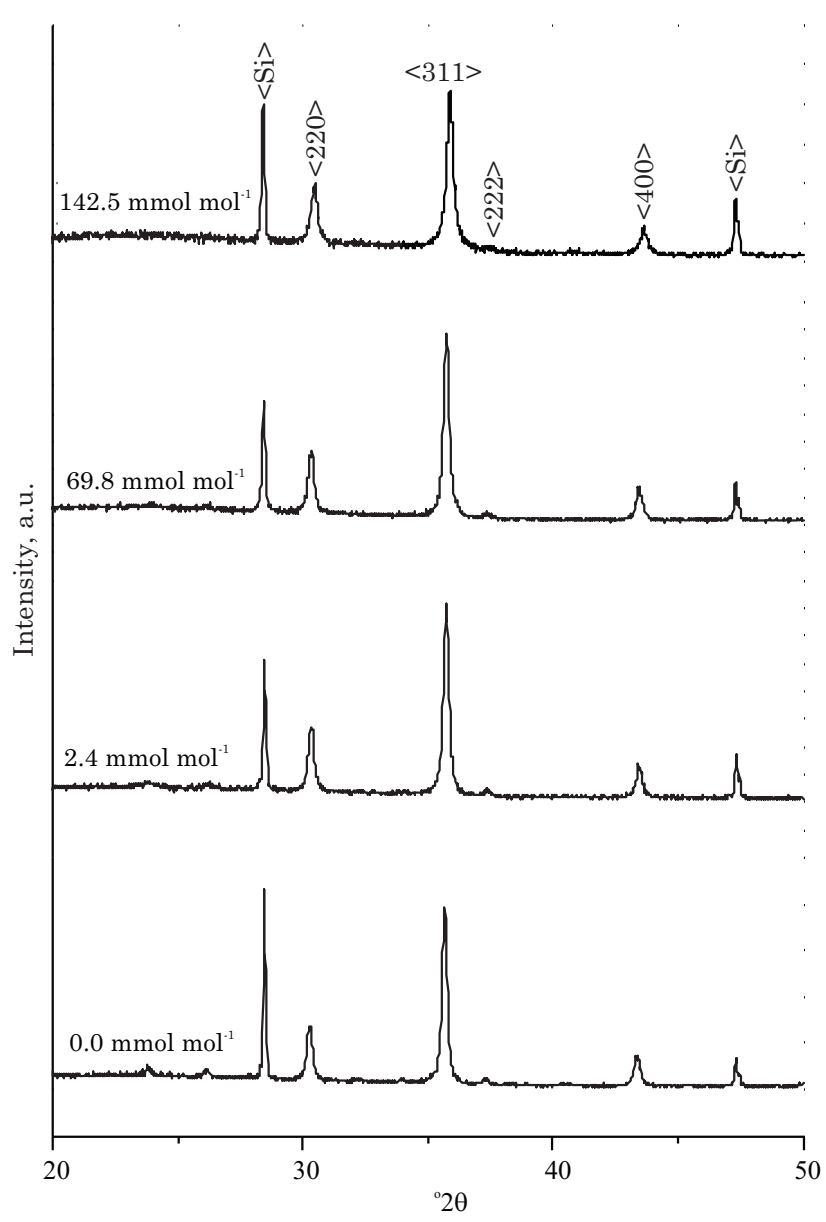

Figure 1. X-ray diffraction patterns for the Alsubstituted maghemites. Si: silicon as internal standard.

were basically related to a decrease in the crystal size of the maghemites caused by $\mathrm{Al}$ entrance into the mineral structure.

Figure 2(a) shows the variation of the mean lattice parameter, $\mathrm{a}_{0}$, calculated and averaged from the six most intense peaks, as a function of the $\mathrm{Al}$ content. The mean unit cell parameter varied from 0.8357 $\mathrm{nm}$, close to the $a_{0}$ value of JCPDS card \# 39-1.346 for pure maghemite, to $0.8306 \mathrm{~nm}$ for maghemite containing $142.5 \mathrm{mmol} \mathrm{mol}^{-1} \mathrm{Al}$. Schwertmann \& Fechter (1984) observed the same negative correlation using natural samples. A detailed inspection of the diffractograms in figure 1 reveals, in addition, changes in the widths of the diffraction peaks with increasing IS. The mean crystalline diameter, calculated from the FWHM of each diffraction peak, decreased linearly with increasing $\mathrm{Al}$ for $\mathrm{Fe}$ substitution (Pereira et al., 1999; Campbell et al., 2000) (Figure 2b).

Figure 3 shows the room temperature (RT) Mössbauer spectra from end-member samples. For maghemites with 0.0 up to $118.8 \mathrm{mmol} \mathrm{mol}^{-1} \mathrm{Al}$, the best spectral fits were obtained using one
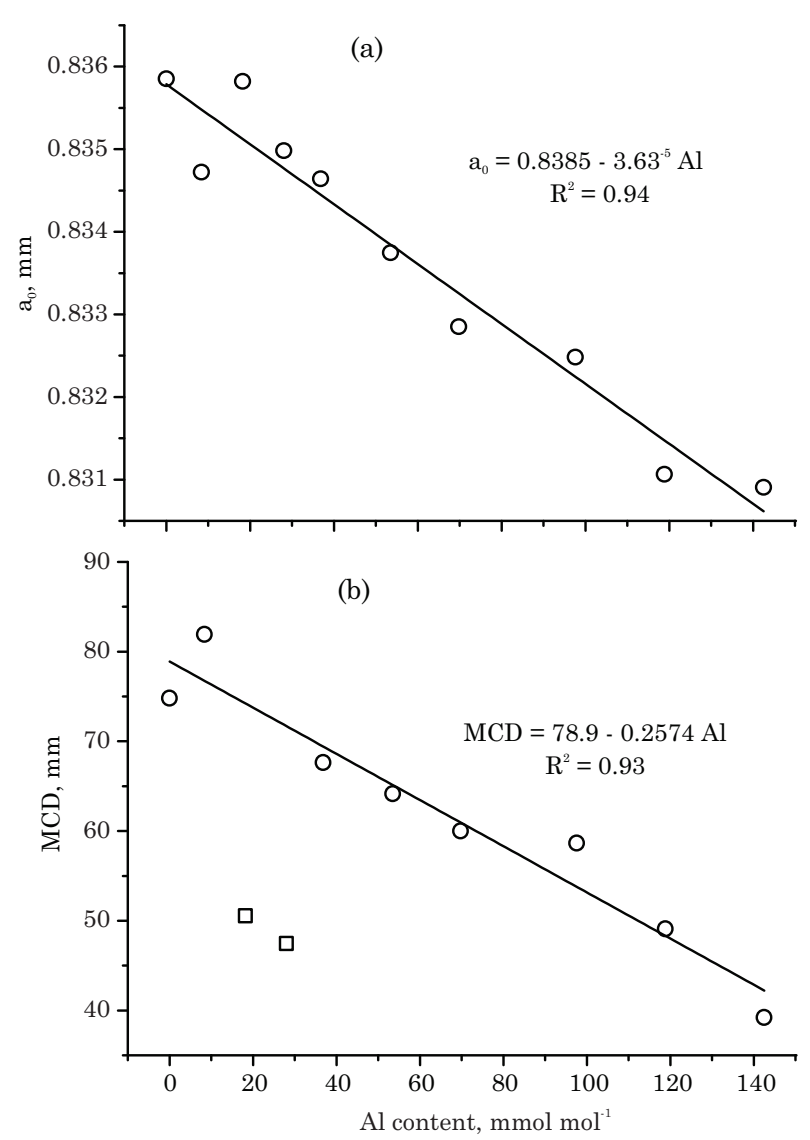

Figure 2. Average lattice parameter $\left(a_{0}\right)$ for the Alsubstituted maghemite (a), and mean crystalline diameter for the $\mathrm{Al}$-substituted maghemites (b), as a function of aluminum content.( $\square$ ) Outlier.

discrete sextet (Figure 3a, Table 2). At $142.5 \mathrm{mmol}$ $\mathrm{mol}^{-1} \mathrm{Al}$, the optimum statistical fit required the application of both a sextet and a doublet (Figure $3 b)$. In this specimen, approximately $32 \%$ of the spectral area was attributed to the doublet (Table 2). The hyperfine parameters for both the sextet and doublet were consistent with high-spin $\mathrm{Fe}^{3+}$, and the lack of spectral evidence for $\mathrm{Fe}^{2+}$ or $\mathrm{Fe}$ with mixed charge $\left(\mathrm{Fe}^{2+/ 3+}\right)$ excluded the presence of residual magnetite in all samples. Mössbauer doublets associated with $\mathrm{Fe}^{3+}$ usually represent either a paramagnetic mineral behaviour, or superparamagnetic iron oxides with very small particle size (Silva et al., 2005). In the present case, superparamagnetism is probably the best explanation for the appearance of a doublet in the sample containing $142.5 \mathrm{mmol} \mathrm{mol}^{-1} \mathrm{Al}$ (Figure $3 \mathrm{~b}$ ). The linewidths $(\Gamma)$ of the Mössbauer spectra tended to increase across all samples with increasing Alsubstitution (Figure 4a) in a manner similar to that observed with X-ray diffraction peak widths (data not shown). These increases in peak widths indicate reduced crystallinity of the maghemite samples caused by Al substitution. 
The Mössbauer data obtained by Costa et al. (1994) at $295 \mathrm{~K}$ from aluminous magnetites prepared by different methods (IS $=0.32 \mathrm{mms}^{-1}$ and $\mathrm{B}_{\mathrm{hf}}=45-52 \mathrm{~T}$ ) were similar to the hyperfine parameters from samples in this study (Table 2). Murad \& Johnston (1987) observed that increasing $\mathrm{Al}$ in the crystalline structure of maghemite decreased $\mathrm{B}_{\mathrm{hf}}$, because of the replacement of ferrimagnetic $\mathrm{Fe}$ by paramagnetic $\mathrm{Al}$. Overall, the magnetic hyperfine field values $\left(B_{h f}\right)$

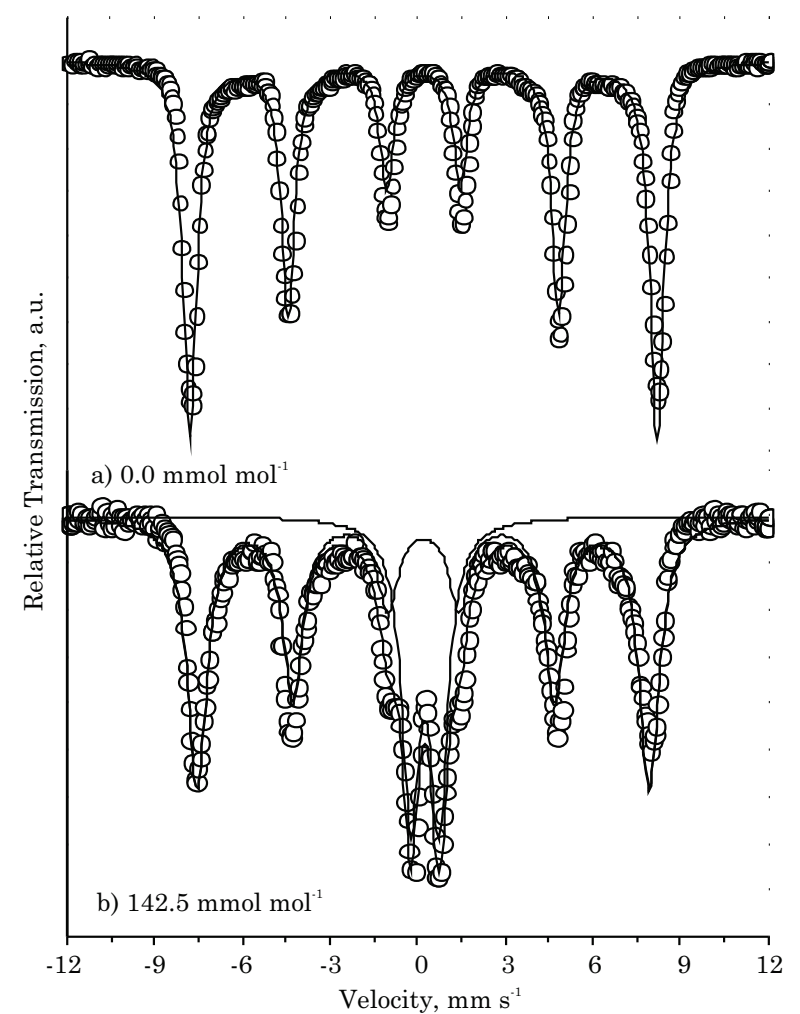

Figure 3. RT Mössbauer spectra for pure maghemite (a) and with $142.5 \mathrm{mmol} \mathrm{mol}^{-1}$ (b) of isomorphic substitution of $\mathrm{Fe}^{3+}$ for $\mathrm{Al}^{3+}$. obtained in this study also decreased with increasing isomorphous substitution, except at $\mathrm{Al}$-substitution rates of $<20 \mathrm{mmol} \mathrm{mol}^{-1}$ where the $\mathrm{B}_{\mathrm{hf}}$ values appeared to increase (Figure 4b). Batista et al. (2010) observed that the mass-specific magnetic susceptibility of these samples also increased with IS. Jesus Filho et al. (1993) calculated the magnetization of synthetic Alsubstituted maghemites and concluded that when substitution occurred in the A sites in a collinear condition, the magnetization of the sample would increase considerably. In other cases, where IS occurred in the B sites with collinear configuration or spin canting, the magnetization values should decrease linearly. These observations suggest that the initial increments of $\mathrm{Al}$ substituted for $\mathrm{Fe}$ in maghemite tend to occupy the A sites, whereas, later increments replace $\mathrm{Fe}$ in the octahedral sites, thereby reducing $B_{\text {hf. }}$ Wolska \& Schwertmann (1989) also affirmed that maghemite can accommodate up to $2 \mathrm{~mol} \% \mathrm{Al}$ in the A site. According to the results from this study (Figure 6), the maximum Al substitution in maghemite would be approximately $18.3 \mathrm{~mol} \%\left[\mathrm{~B}_{\mathrm{hf}}=49.56+0.013 \mathrm{Al}-3.56 \times 10^{-4} \mathrm{Al}^{2}\right.$ $\left.\left(\mathrm{r}^{2}=0.98\right)\right]$, which is close to the value estimated by Wolska \& Schwertmann (1989).

The magnetization vs. applied field curves obtained for all studied samples are shown in figure 5 . These curves are characteristic of systems exhibiting ferrimagnetic behavior. When the magnetizations at $10 \mathrm{kOe}$ are plotted as a function of $\mathrm{Al}$ content (Figure 6), an overall decrease in the magnetization was observed as a consequence of the replacement of ferrimagnetic $\mathrm{Fe}^{3+}$ by paramagnetic $\mathrm{Al}^{3+}$ (Batista et al., 2008). However, when the plot is expanded and the first four points are observed in detail there is clearly an increase in magnetization followed by a decrease at higher substitution levels $\left(\mathrm{M}=65.12+0.213 \mathrm{Al}-0.0144 \mathrm{Al}^{2}, \mathrm{r}^{2}=0.99\right)$. The maximum magnetization occurred with $7.4 \mathrm{mmol} \mathrm{mol}^{-1}$ $\mathrm{Al}$. The same behavior was observed in figure 4(a)

Table 2. Mössbauer hyperfine parameters and sub-spectral areas for the $\mathrm{Fe}_{2-\mathrm{x}} \mathrm{Al}_{\mathrm{x}} \mathrm{O}_{3}$ maghemites

\begin{tabular}{|c|c|c|c|c|c|c|}
\hline Sample & & $\mathrm{IS}^{(1)}( \pm 0.02)$ & $\mathrm{QS}^{(2)}( \pm 0.02)$ & $B_{h f}^{(3)}( \pm 0.2)$ & $\Gamma^{(4)}( \pm 0.2)$ & Area $( \pm 0.3)$ \\
\hline \multicolumn{2}{|l|}{$\mathrm{mmol} \mathrm{mol}^{-1}$} & \multicolumn{2}{|c|}{$-\mathrm{mm} \mathrm{s}^{-1}$} & $\mathrm{~T}$ & $\mathrm{~mm} \mathrm{~s}^{-1}$ & $\%$ \\
\hline 0.0 & Sextet & 0.32 & 0.00 & 49.57 & 0.57 & 100 \\
\hline 8.4 & Sextet & 0.32 & 0.00 & 49.62 & 0.58 & 100 \\
\hline 18.2 & Sextet & 0.32 & -0.01 & 49.70 & 0.60 & 100 \\
\hline 28.1 & Sextet & 0.32 & 0.00 & 49.22 & 0.63 & 100 \\
\hline 36.9 & Sextet & 0.32 & 0.00 & 49.53 & 0.63 & 100 \\
\hline 53.5 & Sextet & 0.32 & 0.00 & 49.22 & 0.62 & 100 \\
\hline 69.8 & Sextet & 0.32 & 0.00 & 48.84 & 0.67 & 100 \\
\hline 97.6 & Sextet & 0.32 & 0.00 & 48.68 & 0.69 & 100 \\
\hline 118.8 & Sextet & 0.32 & 0.00 & 48.29 & 0.73 & 100 \\
\hline \multirow[t]{2}{*}{142.5} & Sextet & 0.31 & -0.01 & 47.94 & 0.83 & 68 \\
\hline & Doublet & 0.36 & -0.98 & - & 0.72 & 32 \\
\hline
\end{tabular}

(1) Relative to $\alpha$-Fe foil at room temperature; ${ }^{(b)}$ quadrupole splitting; ${ }^{(c)}$ magnetic hyperfine interaction; and ${ }^{(\mathrm{d})}$ linewidth. 
with respect to the $\mathrm{B}_{\mathrm{hf}}$ data, and in Batista et al. (2010) using mass-specific magnetic susceptibility measurements.

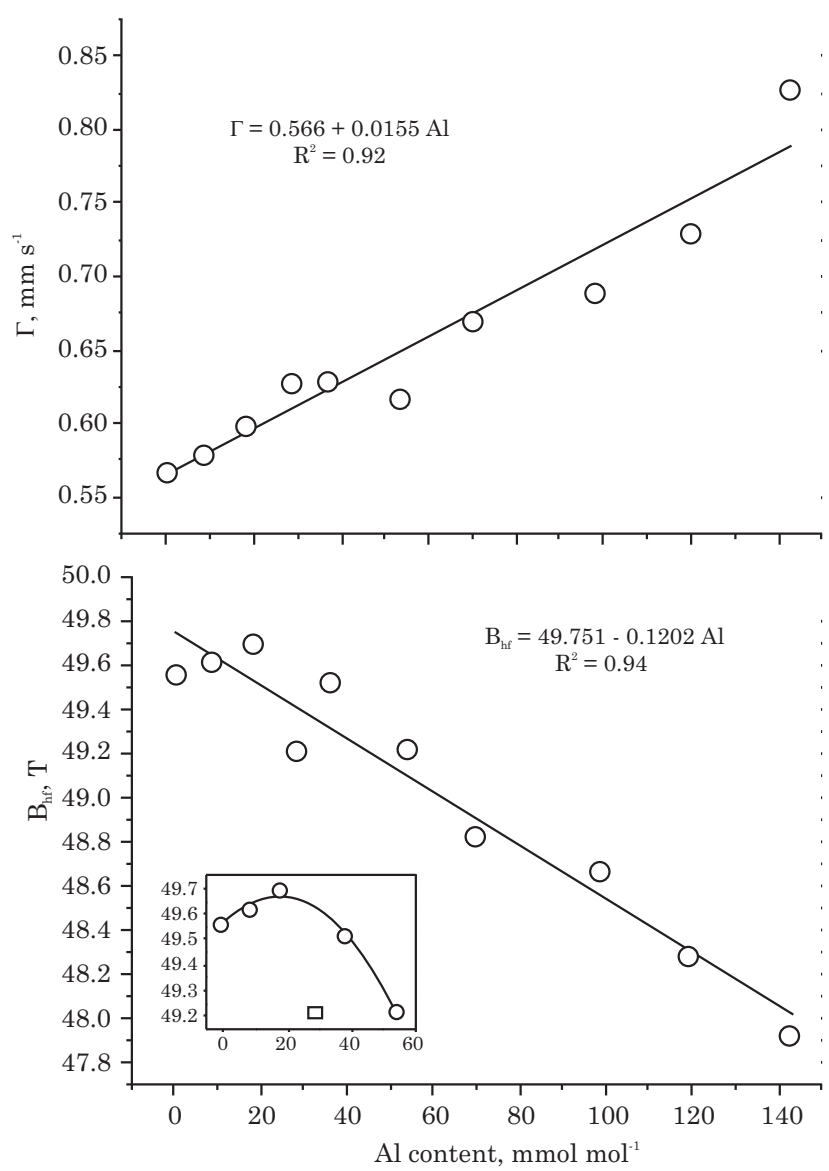

Figure 4. Linewidth $(\Gamma)$ of the Mössbauer spectra (a), and hyperfine magnetic interaction $\left(B_{h f}\right)(b)$ for synthetic aluminum substituted maghemite. () Outlier.

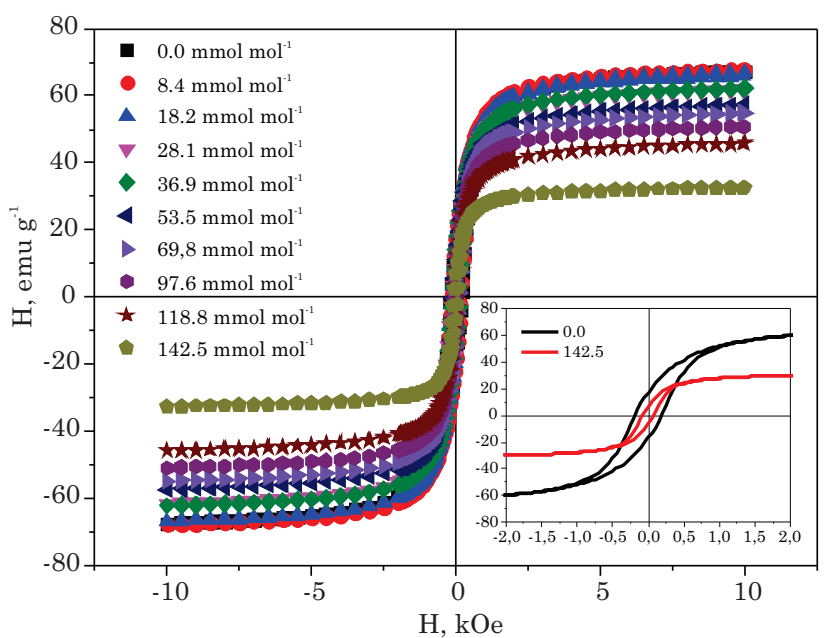

Figure 5. Magnetic hysteresis loops for $\gamma-\mathrm{Fe}_{2-\mathrm{x}} \mathrm{Al}_{\mathrm{x}} \mathrm{O}_{3}$ samples at RT; Insets: 0.0 and $142.5 \mathrm{mmol} \mathrm{mol}^{-1}$ Al-substituted maghemites.

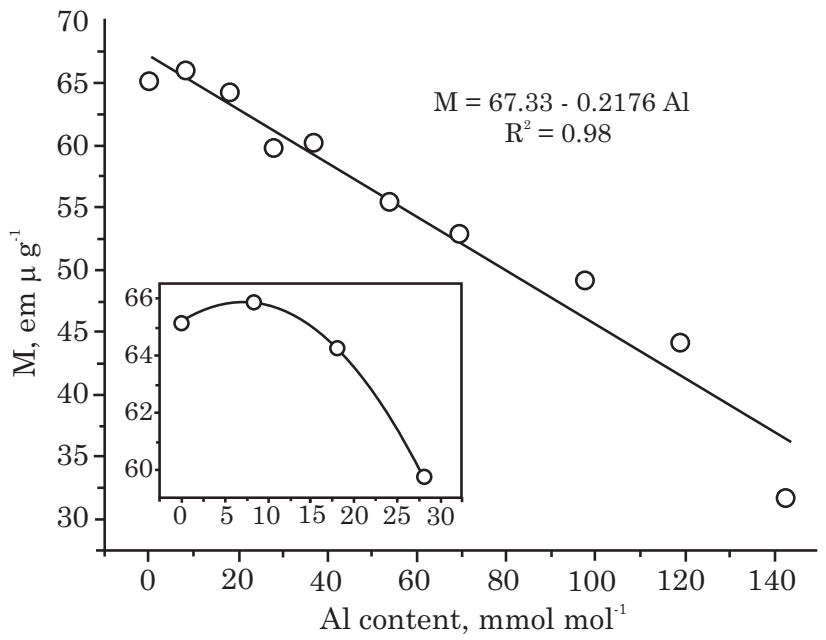

Figure 6. Magnetization at $10 \mathrm{kOe}$ as function of isomorphic substitution of $\mathrm{Fe}^{3+}$ for $\mathrm{Al}^{3+}$ in synthetic substituted maghemite.

\section{CONCLUSIONS}

1. All synthetic samples were identified as maghemites. With the increase of IS the $a$ parameter, $\mathrm{MCD}, \mathrm{B}_{\mathrm{hf}}$ and magnetization decreases. On the other hand, with the increase of IS an increase of linewidth was observed.

2. The sextets obtained were attributed to maghemite and the doublet was attributed to a small maghemite with superparamagnetic behaviour due to the high value of isomorphous substitution.

3. At low levels of isomorphous substitution, the magnetic behavior ( $\mathrm{B}_{\mathrm{hf}}$ and magnetization) of the sample increases, while at high levels of the isomorphous substitution the magnetic behavior $\left(\mathrm{B}_{\mathrm{hf}}\right.$ and magnetization) decreases.

\section{LITERATURE CITED}

ARMSTRONG, J.R.; MORRISH, A.H. \& SAWATZKY, G.A. Mössbauer study of ferric ions in the tetrahedral and octahedral sites of a spinel. Phys. Lett., 23:414-416, 1966.

BATISTA, M.A.; COSTA, A.C.S.; BIGHAM, J.M.; SOUZA JUNIOR, L.G. \& JONES, F.S. Acid dissolution kinetics of synthetic aluminum-substituted maghemites $\left(\gamma-\mathrm{Fe}_{2-\mathrm{x}} \mathrm{Al}_{\mathrm{x}} \mathrm{O}_{3}\right)$. Soil Sci. Soc. Am. J., 75:855-861, 2011.

BATISTA, M.A.; COSTA, A.C.S.; BIGHAM, J.M.; De SANTANA H.; ZAIA, D.A.M. \& SOUZA JUNIOR I.G. Mineralogical, chemical, and physical characterization of Al-substituted maghemites $\left(\gamma-\mathrm{Fe}_{2-\mathrm{x}} \mathrm{Al}_{\mathrm{x}} \mathrm{O}_{3}\right)$. Clays Clay Miner., 58:451-461, 2010.

BATISTA, M.A.; COSTA, A.C.S.; BIGHAM, J.M. \& SOUZA JUNIOR, I.G.Crystallochemical characterization of synthetic Zn-substituted maghemites $\left(\gamma-\mathrm{Fe}_{2-\mathrm{x}} \mathrm{Zn}_{\mathrm{x}} \mathrm{O}_{3}\right) . \mathrm{R}$. Bras. Ci. Solo, 32:561, 2008. 
BOWEN, L.H.; De GRAVE, E. \& BRYAN, A.M. Mössbauer studies in an external field of well-crystallized $\mathrm{Al}$ maghemites made from hematite. Hyperf. Interact., 94:1977-1982, 1994.

CAMPBELL, S.J.; KACZMAREK, W.A. \& HOFFMANN, M. Mössbauer insight to metallurgy; materials science and engineering. Hyperf. Interact., 126: 175, 2000.

CHEN, T.; XU, H.; XIE, Q.; CHEN, J.; JI, J. \& LU, H. Characteristics and genesis of maghemite in Chinese loess and paleosols: mechanism for magnetic susceptibility enhancement in paleosols. Earth Planet. Sci. Lett., 240:790-802, 2005.

COSTA, A.C.S.; SOUZA JUNIOR, I.G.; BATISTA, M.A.; SILVA, K.L.; BELLINI, J.V. \& PAESANO JUNIOR, A. Structural, magnetic and hyperfine characterization of zincsubstituted magnetites. Hyperf. Interact., 175:103-111, 2007.

COSTA, G.M.; De GRAVE, E.; BOWEN, L.H.; De BAKKER P.M.A. \& VANDENBERGHE, L.H. Variable-temperature Moessbauer spectroscopy of nano-sized maghemite and Al-substituted maghemites. Clays Clay Miner.,43:562-568, 1995.

COSTA, G.M.; De GRAVE, E.; VANDENBERCHE, R.E.; BOWEN, L.H. \& De BAKKER, P.M.A.; The center shift in Mössbauer spectra of maghemite and aluminum maghemites. Clays Clay Miner.,42:628-633, 1994.

FERREIRA, B.A.; FABRIS, J.D.; SANTANA, D.P. \& CURI, N. Óxidos de ferro das frações areia e silte de um Nitossolo desenvolvido de basalto. R. Bras. Ci. Solo, 27:405-413, 2003.

JESUS FILHO, M.F.; Da NOVA MUSSEL, W.; QI, Q. \& COEY, J.M.D. Magnetic properties of aluminum-doped $\gamma-\mathrm{Fe}_{2} \mathrm{O}_{3}$. In: INTERNATIONAL CONFERENCE FERRITES, 6., 1993, Tokyo. Proceedings...Tokyo, 1993. p.126-128.

McKEAGUE, J.A. \& DAY, J.H. Dithionite and oxalateextractable $\mathrm{Fe}$ and $\mathrm{Al}$ as aids in differentiating various classes of soils. Can. J. Soil Sci., 46:13-22, 1966.

MURAD, E. \& JOHNSTON, J.H.Iron oxides and oxyhydroxides. In: LONG, G.I., ed. Mössbauer spectroscopy applied to inorganic chemistry. New York, Spring Street, 1987. v.2. p.507.
PEREIRA, S.L.; PFANNES, H.D.; MENDES FILHO, A.A.; MIRANDA PINTO, L.C.B. \& CHÍCARO, M.A. A comparative study of $\mathrm{Ni}, \mathrm{Zn}$ ferrites modified by the addition of cobalt. Mat. Res., 2:231-234, 1999.

RESENDE, M.; COEY, J.M.D. \& ALLAN, J. The magnetic soils of Brazil. Earth Planet. Sci. Lett., 78:322-326, 1986.

ROY, A. \& BHATTACHARYA, J. Removal of $\mathrm{Cu}(\mathrm{II}), \mathrm{Zn}(\mathrm{II})$ and $\mathrm{Pb}(\mathrm{II})$ from water using microwave-assisted synthesized maghemite nanotubes. Chem. Eng. J., 211/ 212:493-500, 2012.

SCHWERTMANN, U. \& CORNELL, R.M. Iron oxides in the laboratory. Preparation and characterization. New York, Verlag Chemie, 1991.

SCHWERTMANN, U. \& FECHTER, H. The influence of aluminum on iron oxides. XI. Aluminum-substituted maghemite in soils and its formation. Soil Sci. Soc. Am. J., 48:1462-1463, 1984.

SILVA, F.D.; COUCEIRO, P.R.C.; FABRIS, J.D.; GOULART, A.T. \& KER, J.C. Magnesioferrite and pedogenetic transformation pathway of magnetic iron oxides in two soil profiles developing on tuffite of the Alto Paranaíba region, State of Minas Gerais, Brazil. R. Bras. Ci. Solo, 29:763-775, 2005.

SILVA, A.R.; SOUZA JUNIOR, I.G. \& COSTA, A.C.S. Suscetibilidade magnética do horizonte B de solos do Estado do Paraná. R. Bras. Ci. Solo, 34:329-337, 2010.

SOUZA JUNIOR, I.G.; COSTA, A.C.S.; VILAR, C.C. \& HOEPERS, A. Mineralogia e suscetibilidade magnética dos óxidos de ferro do horizonte B de solos do Estado do Paraná. Ci. Rural, 40:513-519, 2010.

van OORSCHOT, I.H.M. \& DEKKERSA, M.J. Dissolution behaviour of fine-grained magnetite and maghemite in the citrate-bicarbonate-dithionite extraction method. Earth Planet. Sci. Lett., 167:283-295, 1999.

VILAR, C.C.; COSTA, A.C.S.; HOEPERS, A.\& SOUZA JUNIOR, I.G. Capacidade máxima de adsorção de fósforo relacionada a formas de ferro e alumínio em solos subtropicais. R. Bras. Ci. Solo, 34:1059-1068, 2010.

WOLSKA, E. \& SCHWERTMANN, U. The vacancy ordering and distribution of aluminum ions in $\gamma-(\mathrm{Fe}, \mathrm{Al})_{2} \mathrm{O}_{3}$. Solid State Ionics, 32/33:214-218, 1989. 